\title{
Expression of the synthetic gene of an artificial DDT-binding polypeptide in Escherichia coli
}

Rudolf Moser, Stefan Frey, Karl Münger, Thomas Hehlgans, Stephan Klauser, Hanno Langen, Ernst-L.Winnacker ${ }^{1}$, Ronald Mertz ${ }^{1}$ and Bernd Gutte

Biochemisches Institut der Universitāt Zūrich, Winterthurerstrasse 190 , CH-8057 Zürich, Switzerland, and 'Laboratorium für Molekulare Biologie (Genzentrum), D-8033 Martinsried, FRG

This paper reports the expression of an artificial functional polypeptide in bacteria. The gene of a designed 24-residue DDT-binding polypeptide (DBP) was inserted between the BamHI and Pst cleavage sites of plasmid pUR291. The hybrid plasmid, pUR291-DBP, was cloned in Escherichia coli JM109. After induction by isopropyl- $\beta$-D-thiogalactopyranoside a fusion protein was expressed in which DBP was linked to the $\mathrm{COOH}$-terminus of $\beta$-galactosidase. DBP, which is stable to trypsin, was obtained by tryptic digestion of the fusion protein and subsequent fractionation of the tryptic peptides by reversed-phase h.p.l.c. Recombinant and chemically synthesized DBP showed identical chromatographic properties, amino acid composition, and chymotryptic digestion patterns. Both the $\beta$-galactosidase-DBP fusion and isolated recombinant DBP bound DDT. The fusion protein was 25 times as potent as the designed 24-residue DBP in activating a cytochrome $\mathbf{P}-\mathbf{4 5 0}$ model system using equimolar catalytic amounts of the two proteins.

Key words: protein design/DDT-binding polypeptide/pUR291 hybrid plasmid/fusion protein/recombinant DDT-binding polypeptide

\section{Introduction}

Artificial, man-made proteins may be useful for research, biotechnology and medicine, yet our limited understanding of the relationship between amino acid sequence and folding of a polypeptide chain is, at present, an unsurmountable obstacle to the design of novel biologically active proteins. Artificial functional peptides, however, have been prepared by several authors (reviewed by Gutte et al., 1984; Moser et al., 1985).

We have designed a 24-residue polypeptide (Moser et al., 1983) (Figure 1) capable of binding the insecticide DDT $\sim 1000$ times more strongly than bovine serum albumin, a well-known carrier of hydrophobic molecules $\left(k_{\mathrm{D}}\right.$ of the peptide-DDT complex in 55\% aqueous ethanol $=0.9 \times 10^{-6} \mathrm{M}$ ). The tools for the design were model building and secondary structure prediction (Chou and Fasman, 1978; Levitt, 1978). The artificial DDTbinding polypeptide (DBP) was synthesized by the solid phase method (Merrifield, 1963; Barany and Merrifield, 1979) and was shown by c.d. measurements in $55 \%$ aqueous ethanol to contain $42 \% \beta$-sheet (Moser, 1986) which agreed well with the $\beta$-sheet content of the model (Moser et al., 1983). The purified synthetic product was homogeneous by various analytical criteria and could be crystallized; the crystals, however, were not suitable for Xray structural analysis.

The present work was attempted mainly for two reasons: (i) it was useful to demonstrate that genes of non-natural polypeptides could be efficiently expressed in a suitable organism, and (ii) if there was expression, the physicochemical and biological properties of the primary translation product (inevitably a fusion protein containing the DBP sequence) could be studied, and DDT binding and metabolism by a $\mathrm{DBP}^{+}$and a $\mathrm{DBP}^{-}$strain of E. coli could be compared.

\section{Materials and methods}

\section{Construction of the hybrid plasmid pUC8-DBP}

The eight DNA fragments constituting the double-stranded DNA of the DBP gene (Figure 2, nucleotide sequences in boxes) for insertion between the BamHI and PstI cleavage sites of the polylinker of plasmid pUC8 (Vieira and Messing, 1982) were synthesized by the solid phase phosphoramidite method (Beaucage and Caruthers, 1981) using protected deoxyribonucleotidemorpholino-methoxyphosphines (Dörper and Winnacker, 1983). After synthesis and complete deprotection they were purified by electrophoresis on preparative denaturing $16 \%$ polyacrylamide gels. The bands containing the target oligodeoxynucleotides were
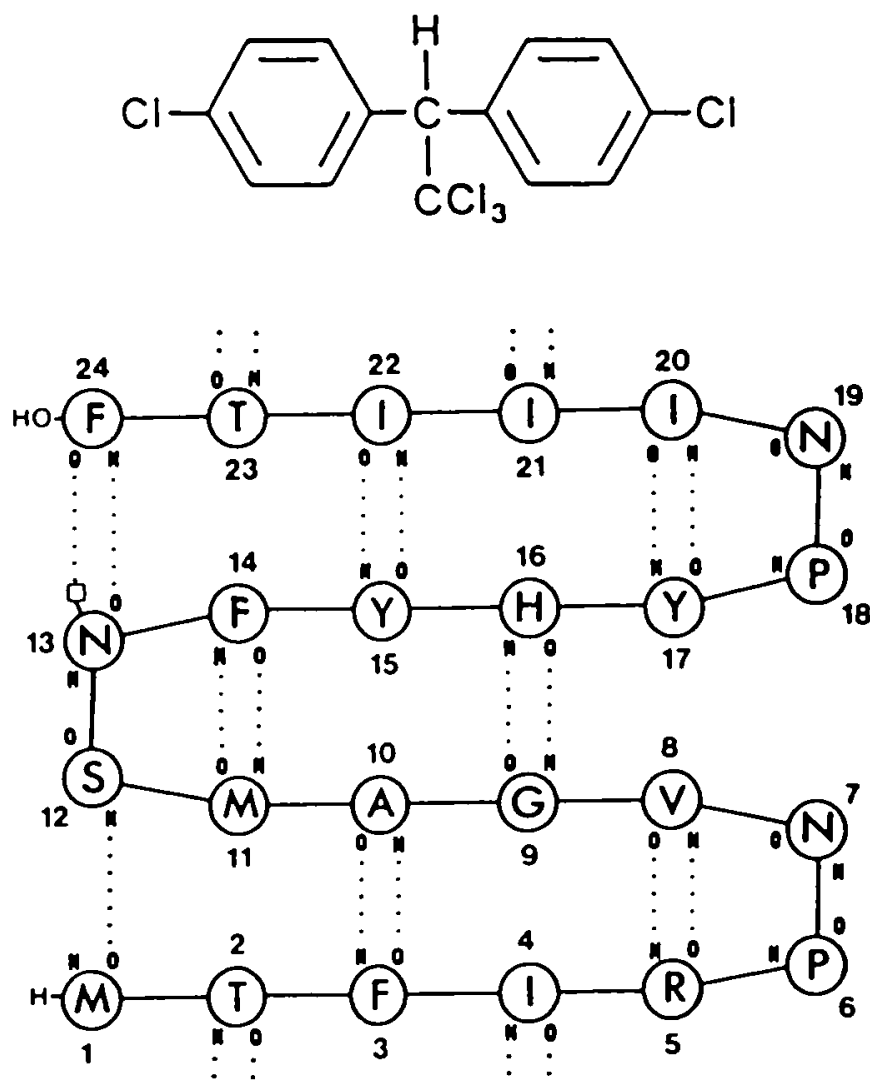

Fig. 1. Structural formula of 4,4'-DDT [1,1,1-trichloro-2,2-bis(4-chlorophenyl)-ethane] (top) and sequence and proposed secondary structure of the designed 24-residue DDT-binding polypeptide (bottom). Dotted lines indicate hydrogen bonds between NH and $\mathrm{CO}$ groups of the backbone and side chains. 


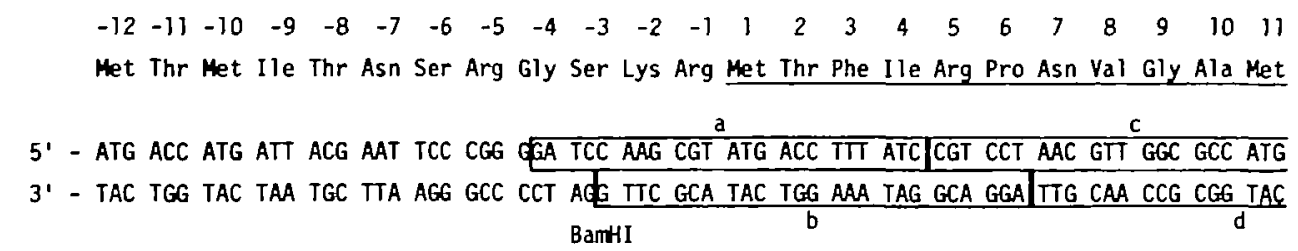

$\begin{array}{lllllllllllll}12 & 13 & 14 & 15 & 16 & 17 & 18 & 19 & 20 & 21 & 22 & 23 & 24\end{array}$

Ser Asn Phe Tyr His Tyr Pro Asn Ile Ile Ile Thr Phe Stop Stop Leu Gin Pro Ser Leu Ala Leu

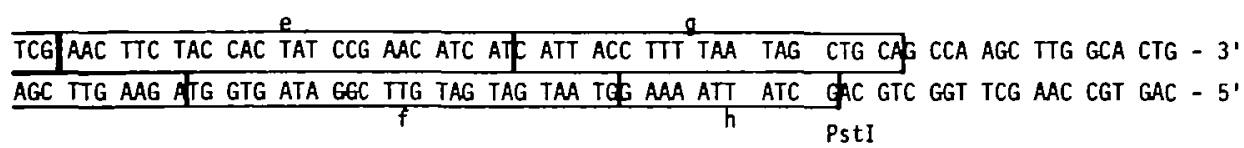

Fig. 2. Structure of the gene of the artificial 24-residue peptide inserted between the BamHI and PstI cleavage sites of the polylinker of plasmid pUC8 (Vieira and Messing, 1982). The synthetic fragments constituting the double-stranded DNA of the gene are lettered a-h. Codons -12 to -6 encode the $\mathrm{NH}_{2}$-terminal residues of $\beta$-galactosidase, codons -5 to -3 are part of the polylinker, and codons -2 and -1 encode the basic residues Lys and Arg. The codons for the artificial 24-residue peptide are numbered 1-24 and are followed by two stop codons. Expression would yield a 36-residue 'precursor' comprising residues -12 to 24 . The residues of the designed DDT-binding polypeptide are underlined.

extracted with water, and urea and salts were removed by reversephase h.p.l.c. on a C-18 column (Brownlee) using a gradient of acetonitrile in water buffered with $100 \mathrm{mM}$ triethylammonium acetate $(\mathrm{pH} 7.0)$. Assembly of the DBP gene followed a previously published procedure (Rommens et al., 1983). The mixture of the oligodeoxynucleotides b to $\mathrm{g}(50 \mathrm{pmol}$ each in $40 \mu \mathrm{l})$ was incubated at $\mathrm{pH} 7.4$ and $37^{\circ} \mathrm{C}$ in the presence of $1 \mathrm{mM}$ ATP and T4 polynucleotide kinase for $45 \mathrm{~min}$. It was then heated to $95^{\circ} \mathrm{C}$ for $3 \mathrm{~min}$ and, after the addition of oligodeoxynucleotides a and $\mathrm{h}$, allowed to cool to $4^{\circ} \mathrm{C}$ overnight. Ligation was carried out at $16^{\circ} \mathrm{C}$ for $16 \mathrm{~h}$ using fresh ATP $(1 \mathrm{mM})$ and T4 polynucleotide ligase $(50 \mu \mathrm{l}, \mathrm{pH} 7.4)$. The ligation mixture was separated on a $12 \%$ polyacrylamide gel and stained with ethidium bromide. The band of correct length (90 bp) was extracted (Maxam and Gilbert, 1980) and the synthetic DBP gene was obtained from the solution by two-fold precipitation with ethanol. In order to construct the hybrid plasmid pUC8-DBP, pUC8 DNA $(5 \mu \mathrm{g})$ was digested with BamHI and PstI and the large fragment isolated by electrophoresis on a $1 \%$ agarose gel. One $\mu \mathrm{g}$ of the linearized vector was ligated with the synthetic gene present in a tenfold molar excess $(0.34 \mu \mathrm{g})$. The hybrid plasmid formed was transfected to competent $E$. coli JM83 cells which were then incubated on agar plates at $37^{\circ} \mathrm{C}$ for $24 \mathrm{~h}$ in the presence of ampicillin $(50 \mu \mathrm{g} / \mathrm{ml})$ and $\mathrm{Xgal}$ (5-bromo-4-chloro-indolyl- $\beta$ D-galactopyranoside, $0.9 \mathrm{mg}$ per plate). White clones were mainly formed. In contrast with blue clones which are obtained after transformation of strain JM83 by pUC8 (Ullmann et al., 1967; Langley et al., 1975), white clones have no $\beta$-galactosidase activity indicating that they harbour the hybrid plasmid. To check size and sequence of the synthetic insert, the hybrid plasmid of 5-ml cultures of 18 white clones was isolated (Birnboim and Doly, 1979; Marko et al., 1982) and digested with BamHI and PstI. In all cases the small fragment of these cleavages contained the expected 90 bp as shown by polyacrylamide gel electrophoresis. Six of the small fragments (or synthetic inserts) were sequenced by the method of Maxam and Gilbert (Maxam and Gilbert, 1980) and were found to have the correct sequence.

Construction of the hybrid plasmid pUR291-DBP (Figure 3) Plasmid pUR291 (Rüther and Müller-Hill, 1983) was treated with restriction endonucleases $B a m \mathrm{HI}$ and $P s t \mathrm{I}$ and the digestion mixture separated by electrophoresis on a $1 \%$ agarose gel. The large fragment of pUR291 was ligated to the DBP gene isolated from
Table I. DDT degradation by hemin-cysteine in $24 \mathrm{~h}$ in the presence of the $\beta$-galactosidase-DBP fusion protein

\begin{tabular}{lcl}
\hline Protein $(\mu \mathrm{M})$ & DDT degradation $(\mathscr{W})^{\mathbf{a}}$ \\
\hline No protein added & & 51 \\
$\beta$-Galactosidase-DBP & $0.24^{\mathrm{b}}$ & 59.5 \\
DBP & 2.45 & 54.5 \\
& 120 & 86 \\
$\beta$-Galactosidase & 6 & 51 \\
\hline
\end{tabular}

aThe concentration of cysteine is rate-limiting.

b The low solubility of $\beta$-galactosidase-DBP in $0.05 \mathrm{M}$

$\mathrm{NH}_{4} \mathrm{HCO}_{3}$-dimethylformamide $(5: 6, \mathrm{v} / \mathrm{v})$ did not allow protein

concentration-degradation rate studies.

a BamHU/Pst digest of pUC8-DBP. The pUR291-DBP hybrid plasmid was transfected into competent $E$. coli JM109 cells. Ampicillin-resistant clones containing the hybrid plasmid were identified by digestion of the extractable DNA of quick lysates with BamHI/PstI and EcoRI/PstI, respectively, and gel electrophoretic analysis of the restriction patterns.

Expression and isolation of the $\beta$-galactosidase-DBP fusion protein

Electrophoresis of cell extracts of pUR291- and pUR291-DBPtransformed $E$. coli JM109 on $7.5 \%$ SDS-polyacrylamide gels showed that IPTG induced strongly both $l a c Z^{\prime}$ and the lac $Z^{\prime}$-DBP fusion. Maximum yields were obtained by addition of IPTG (1-2 $\mathrm{mM})$ to transformed $E$. coli JM109 during logarithmic growth $\left(\mathrm{E}_{600}, \sim 0.8\right)$ and incubation at $25^{\circ} \mathrm{C}$ for $\sim 20 \mathrm{~h}$. Cells were centrifuged, sonicated and extracted with a Tris buffer, $\mathrm{pH}$ 7.4 (20 mM Tris- $\mathrm{HCl}, 10 \mathrm{mM} \mathrm{MgCl}_{2}, 10 \mathrm{mM} \beta$-mercaptoethanol) to remove soluble proteins. The insoluble portions were extracted further with buffer containing $8 \mathrm{M}$ urea, $0.1 \mathrm{M} \mathrm{NH}_{4}$ $\mathrm{HCO}_{3}, 1 \mathrm{mM} \mathrm{MgCl}, 1 \mathrm{mM}$ dithiothreitol. After centrifugation, aliquots of the supernatants and the pellets were analyzed by electrophoresis (Figure 4). The supernatants were dialyzed against water and lyophilized. All steps of the isolation procedure were performed at $4^{\circ} \mathrm{C}$. The lyophilized products were purified further by gel filtration on Sephacryl S-300 in a Tris-urea buffer, $\mathrm{pH} 7.4(8 \mathrm{M}$ urea, $20 \mathrm{mM}$ Tris $-\mathrm{HCl}, 10 \mathrm{mM} \beta$ mercaptoethanol). Fractions containing the putative $\beta$ - 

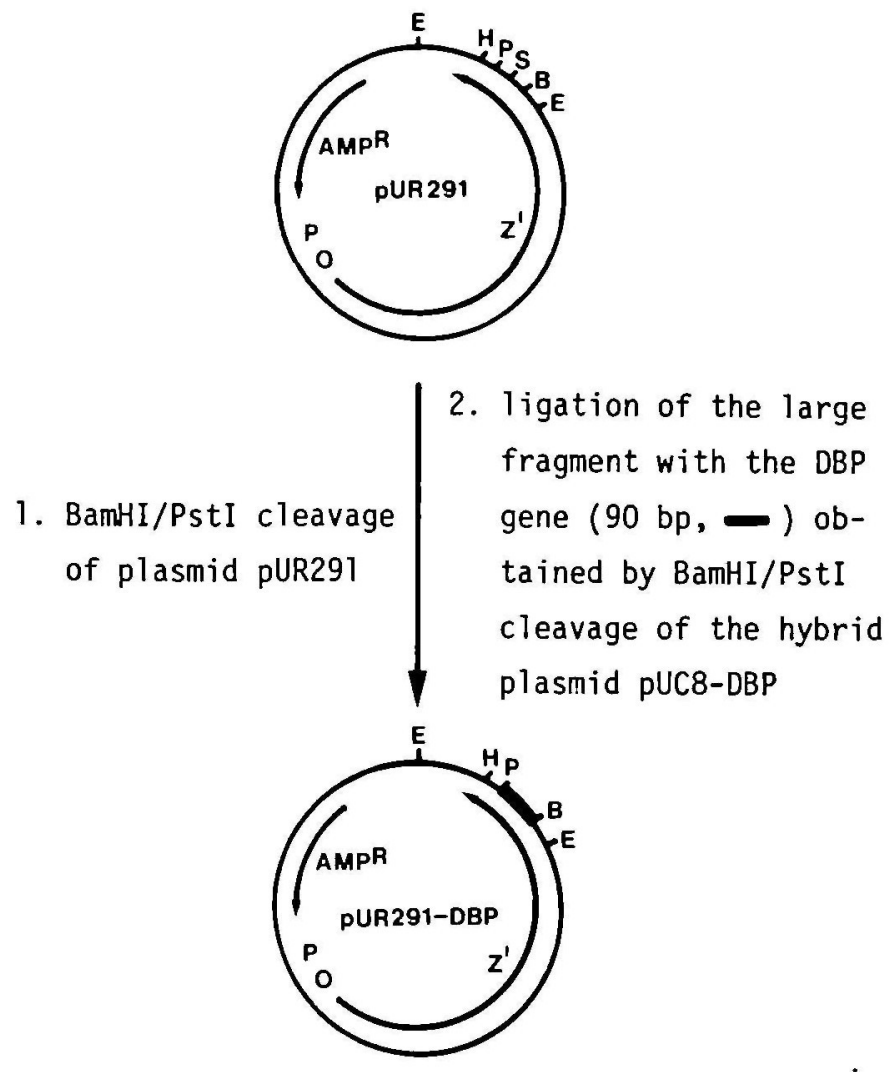

Fig. 3. Construction of the hybrid plasmid pUR291-DBP by insertion of the DBP-coding portion of pUC8-DBP (Figure 2) into BamHI/Pst-treated pUR291 (Rüther and Müller-Hill, 1983). Expression of pUR291-DBP in $E$. coli yields a 1050-residue fusion protein of the following sequence: $\beta$-galactosidase (1-1021)-Arg-Gly-Ser-Lys-Arg-DBP. Abbreviations of restriction sites: E, EcoRI; B, BamHI; S, Sall; P, PsII; H, HindIII.

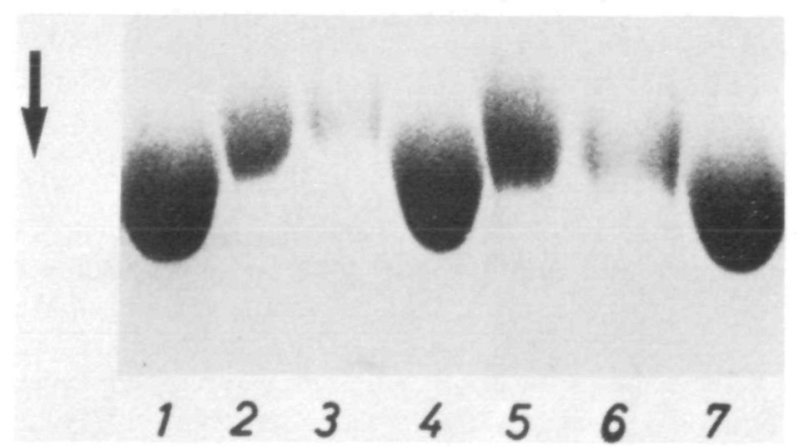

Fig. 4. SDS-PAGE of wild-type E. coli $\beta$-galactosidase (lanes 1,4 and 7), $\beta$-galactosidase of pUR291-transformed $E$. coli JMI09 (lanes 2 and 3), and $\beta$-galactosidase-DBP fusion protein of pUR291-DBP-transformed $E$. coli JM 109 (lanes 5 and 6). Bands move from top to bottom; only part of the $300 \times 180 \mathrm{~mm}$ gel is shown. In lanes 2 and 5, aliquots of the urea extracts of disrupted cells were applied. The pellets of these extracts were boiled in $0.125 \mathrm{M}$ Tris-HCl, $\mathrm{pH} 6.8$, containing $10 \%$ glycerol, $5 \% \beta$-mercaptoethanol, and 2\% SDS and the supernatants of the centrifuged mixtures were applied to lanes 3 and 6.

galactosidase-DBP fusion protein or the $\beta$-galactosidase of the control were identified by SDS-PAGE, pooled, dialyzed against water at $4^{\circ} \mathrm{C}$ and lyophilized.

Isolation and characterization of recombinant $D B P$

The putative $\beta$-galactosidase-DBP fusion protein of pUR291-DBP-transformed $E$. coli JM109 and the $\beta$-galactosidase of the control were carboxymethylated (Craven et al., 1965) and then cleaved by trypsin (Steers et al., 1965). The mixtures of the tryptic peptides of control and sample were partially fractionated by reversed-phase h.p.l.c. (Figure 5A and B, respectively) on a C-8 column $(250 \times 4 \mathrm{~mm}$, Macherey and Nagel) using $0.1 \%$ TFA (trifluoroacetic acid) as the first solvent and $60 \%$ acetonitrile in $0.1 \%$ TFA as the second solvent. The recombinant DBP (Figure 5B, arrow) was rechromatographed and then cleaved by chymotrypsin. Figure 5C shows the h.p.l.c. chromatogram of the chymotryptic peptides of recombinant DBP. Chymotryptic hydrolysis of chemically synthesized DBP followed by h.p.l.c. gave an almost identical digestion pattern.

DDT degradation by cytochrome P-450 models (Sakurai, 1980) Mixtures of DDT $(0.12 \mathrm{mM})$, hemin $(0.05 \mathrm{mM})$, cysteine $(12 \mathrm{mM})$ and various proteins (concentrations given in Table I) were incubated in $0.05 \mathrm{M} \mathrm{NH}_{4} \mathrm{HCO}_{3}$-dimethylformamide (5:6, $\mathrm{v} / \mathrm{v})$ at $37^{\circ} \mathrm{C}$ for $24 \mathrm{~h}$. DDT degradation and product formation (Moser $e t$ al., 1985) were determined quantitatively (Table I) by h.p.l.c. on an RP-300-5C8-column using a gradient of acetonitrile in $0.1 \%$ TFA.

\section{Results and discussion}

The $p U C 8-D B P$ hybrid plasmid

To derive the sequence of the DBP gene the codon usage of highly expressed $E$. coli proteins (Grosjean and Fiers, 1982) was chosen except for those positions at which restriction sites had to be created or abolished. The DBP gene was synthesized (Beaucage and Caruthers, 1981) and inserted between the BamHI and PstI cleavage sites of the polylinker region of plasmid pUC8 (Figure 2). The hybrid plasmid formed was cloned in E. coli JM83 (Yanisch-Perron et al., 1985). Gel electrophoresis and DNA sequence analysis (Maxam and Gilbert, 1980) showed that the cloned DBP gene, isolated from the BamHI/Pst digest of the hybrid plasmid of transformed $E$. coli JM83 cells, had the expected size and sequence. Expression would yield a 36-residue fusion protein (Figure 2) from which the desired 24-residue DDT-binding polypeptide could be obtained by tryptic cleavage at the pair of basic residues preceding the $\mathrm{NH}_{2}$-terminal methionine of DBP. The internal Arg-Pro bond is not susceptible to tryptic hydrolysis. Antibodies against DBP cross-reacted strongly with a chemically synthesized reference sample of the 36-residue fusion protein (Figure 2). However, radioimmunoassays of samples of the cytosol, detergent extracts of the membranes, and culture medium taken at various stages of the logarithmic and stationary growth of the transformed $E$. coli JM83, were all negative. The lack of measurable amounts of translation product seemed to be caused mainly by the instability of the putative 36-residue fusion protein towards endogenous proteases, because neither exogenously added 24-residue nor 36-residue polypeptide could be detected immunologically in cell extracts even in the presence of protease inhibitors. Similar observations on analogous fusions and nonsense fragments of $\beta$-galactosidase have been made previously (Goldschmidt, 1970; Itakura et al., 1977).

\section{The pUR29I-DBP hybrid plasmid}

We surmized that the fusion of DBP with the $\mathrm{COOH}$-terminus of $\beta$-galactosidase might yield a more stable product. Using this scheme, Itakura et al. (1977) had been able to demonstrate the expression in $E$. coli of the synthetic gene of somatostatin, a 14-residue peptide hormone. Fusions employing $\beta$-galactosidase as a protective 'carrier' can be easily analyzed by gel electrophoresis and assays of the enzymatic activity. We chose 
A

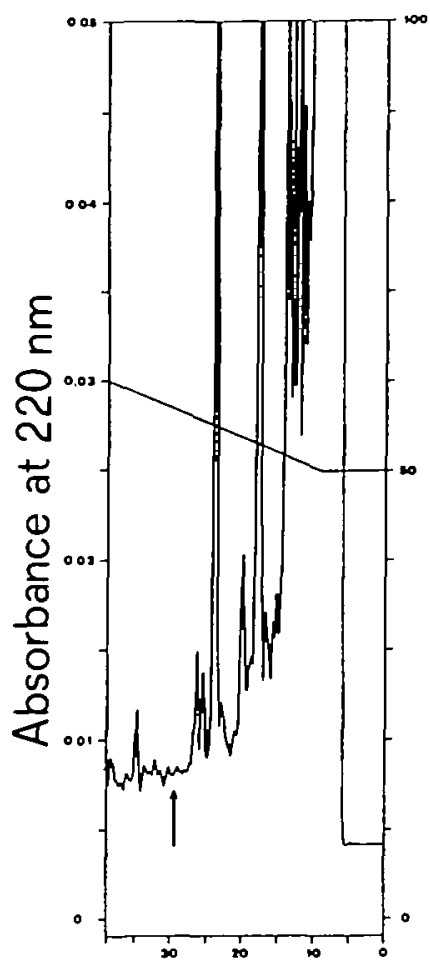

B

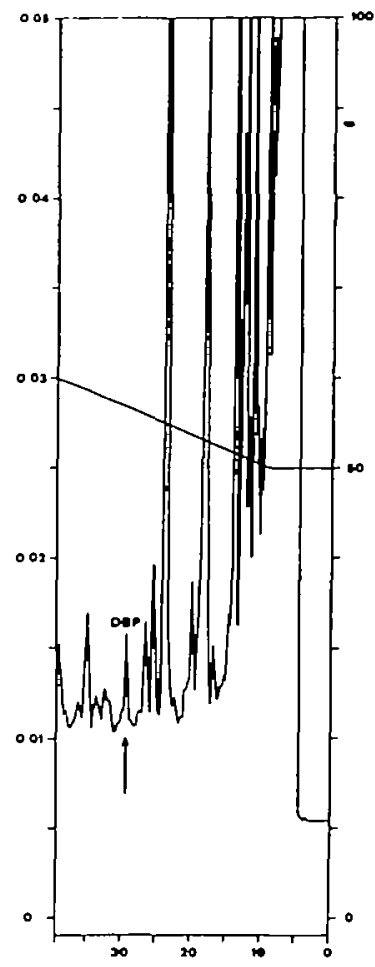

C

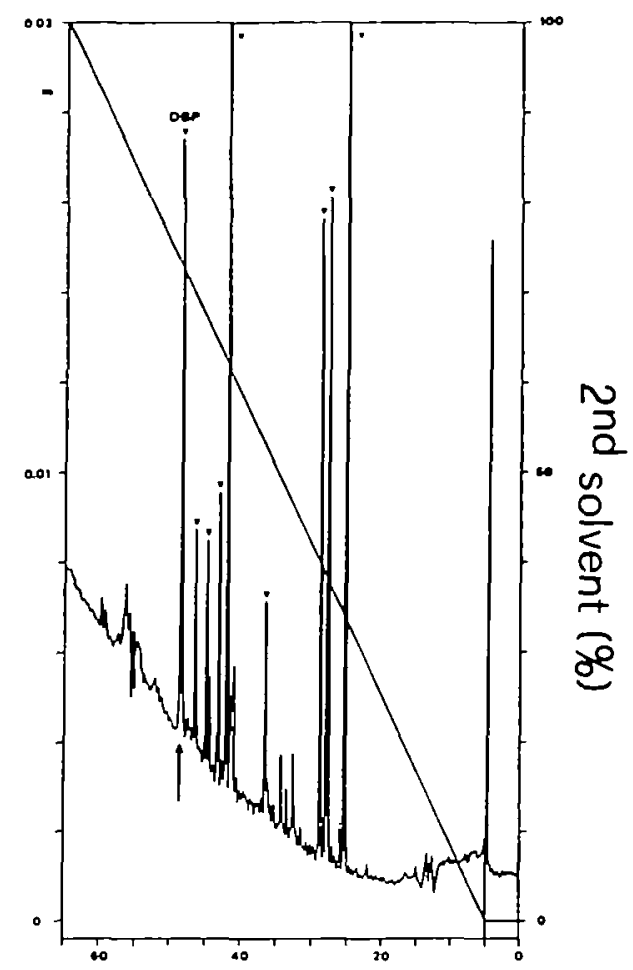

Elution volume (ml)

Fig. 5. Isolation of recombinant DBP from the tryptic digest of the carboxymethylated $\beta$-galactosidase-DBP fusion protein by reverse-phase h.p.l.c. on a C-8 column. (A,B) Partial resolution of the tryptic digests of $\beta$-galactosidase of the control and $\beta$-galactosidase-DBP fusion protein, respectively;

(C) chymotryptic peptide map of recombinant DBP solated from the DBP peak in B. The peaks marked (v) appeared in the chymotryptic digest of both recombinant and chemically synthesized DBP and had almost the same relative sizes. The arrow in A, B and C indicates the position of chemically synthesized DBP chromatographed under identical conditions.

plasmid pUR291 (Rüther and Müller-Hill, 1983) (Figure 3) as the expression vector. The lac $Z^{\prime}$ portion of the $\beta$-galactosidase gene of pUR291 can be induced by inducers of the lac system and is extended at the 3 '-end by a polylinker region. The hybrid plasmid pUR291-DBP was constructed as depicted in Figure 3 and was cloned in $E$. coli JM109 (Yanisch-Perron et al., 1985). After the expected structure of the DBP gene in the hybrid plasmid of transformed cells had been confirmed by gel electrophoretic analysis of restriction patterns, the expression of the putative 1050 -residue $\beta$-galactosidase-DBP fusion protein could be demonstrated and was compared with the expression of lac $Z^{\prime}$ by pUR291-transformed $E$. coli JM109. Cells were incubated with IPTG, sonicated, extracted with $20 \mathrm{mM}$ Tris - HCl buffer, $\mathrm{pH} 7.4$, and centrifuged. Extracts and resuspended pellets were assayed for $\beta$-galactosidase activity. using 0 -nitrophenyl$\beta$-D-galactopyranoside as substrate; the product formed (onitrophenol) was determined quantitatively at $420 \mathrm{~nm}$ (Steers et al., 1971). In pUR291-DBP-transformed cells $59 \%$ of the measurable activity was found in the extract, the remainder was in the pellet. In contrast, $95 \%$ of the measurable $\beta$-galactosidase activity of pUR291-transformed cells was soluble in the Tris buffer indicating that the putative fusion protein had reduced solubility. The enzyme assays also revealed that the specific activity of the presumptive $\beta$-galactosidase-DBP fusion protein was $\sim 20 \%$ lower than that of $\beta$-galactosidase isolated from pUR291-transformed $E$. coli JM109. This correlated with differences in the structural stability of the two products. Whereas the putative $\beta$-galactosidase-DBP fusion was partially suscep- tible to digestion by cellular proteases, the $\beta$-galactosidase of the control was stable. Digestion was increased considerably when pUR291-DBP-transformed $E$. coli cells were grown after IPTG induction at $37^{\circ} \mathrm{C}$.

\section{Isolation and characterization of recombinant DBP}

Transformed $E$. coli cells were sonicated and extracted with

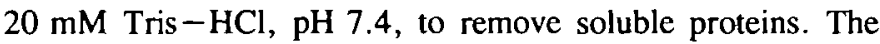
pellets were treated with $0.1 \mathrm{M} \mathrm{NH}_{4} \mathrm{HCO}_{3}$ containing $8 \mathrm{M}$ urea and $1 \mathrm{mM}$ dithiothreitol. After centrifugation the supernatants were dialyzed against water, lyophilized, and purified further by gel filtration on Sephacryl S-300. Gel electrophoresis (Figure 4) showed that, as expected, both the presumptive $\beta$-galactosidase-DBP fusion protein and $\beta$-galactosidase of the control displayed a bigger relative molecular mass than wild type $\beta$-galactosidase from $E$. coli (1023 residues). This scheme of isolation of the $\beta$-galactosidase-DBP fusion protein was more effective than affinity chromatography on Sepharose-4B-linked $p$-aminophenyl- $\beta$-D-thiogalactopyranoside (Cuatrecasas, 1970) because the fusion protein was only poorly soluble in buffers not containing urea and bound only weakly to the immobilized substrate analogue.

The putative $\beta$-galactosidase-DBP fusion protein and the $\beta$ galactosidase of the control were then carboxymethylated and cleaved by trypsin. Solid phase radioimmunoassays, using rabbit antibodies against chemically synthesized DBP and ${ }^{125} \mathrm{I}$ labelled protein $A$; were positive for the mixture of the tryptic peptides of the sample derived from the pUR291-DBP- 
transformed strain but were negative for the tryptic digests of wild-type $\beta$-galactosidase and $\beta$-galactosidase of the pUR291-transformed strain (results not shown). H.p.l.c. analysis of the tryptic peptides revealed that the digest of the putative $\beta$-galactosidase-DBP fusion protein contained a peptide that eluted at the same position as chemically synthesized DBP (Figure $5 B$, arrow). This peptide was not present in the digest of the $\beta$ galactosidase from the control (Figure 5A, arrow). The material under the marked peak of Figure 5B was rechromatographed for further analytical characterization. Amino acid analysis after acid hydrolysis of the recombinant product showed excellent agreement with the values obtained for the synthetic 24-residue DDTbinding polypeptide, and resolution by h.p.l.c. of the chymotryptic digests of recombinant product and chemically synthesized DBP gave almost identical peptide maps (Figure 5C).

Based on the enzymatic activity of the fusion protein and quantitative amino acid analysis, the yield of recombinant DBP was $41 \%$ after Sephacryl S-300 chromatography of the ureaextractable material and $28 \%$ after tryptic digestion of the purified fusion protein and resolution of the digest by h.p.l.c. Recombinant and chemically synthesized DBP were indistinguishable in their DDT-binding properties.

Characterization of the $\beta$-galactosidase-DBP fusion protein

The dissociation constant of the DBP-DDT complex in $55 \%$ aqueous ethanol was $0.9 \times 10^{-6} \mathrm{M}$ as determined by the method of Hummel and Dreyer (1962). In a preliminary t.l.c. assay using $20 \%$ dimethylsulfoxide in $0.05 \mathrm{M} \mathrm{NH}_{4} \mathrm{HCO}_{3}$ as solvent, the DDT binding of the $\beta$-galactosidase-DBP fusion was of the same order of magnitude. Wild-type $\beta$-galactosidase did not have measurable DDT-binding activity. Moreover, the $\beta$-galactosidase-DBP fusion protein was 25 times as potent as an equimolar amount of free DBP in stimulating the degradation of DDT by a cytochrome P-450 model system (Table I). The model system alone (hemin and excess cysteine; Sakurai, 1980) was able to degrade $51 \%$ of the added DDT in $24 \mathrm{~h}$. Wild-type $\beta$-galactosidase had no effect. Preliminary studies showed that the increase of the DDT degradation rate depended on the concentration of DBP (Table I). The nature of this observation will be investigated further.

This paper describes for the first time the cloning and expression in $E$. coli of a designed, artificial polypeptide based on the construction of the pUR291-DBP gene hybrid plasmid. The DBP moiety of the isolated $\beta$-galactosidase-DBP translation product was more active in DDT degradation than free DBP and the bacterial strain transformed by the hybrid plasmid can now be used to study the biological activity of the $\beta$-galactosidase-DBP fusion protein in vivo. The system also lends itself to investigations of the relationship between amino acid sequence and DDT binding of the designed 24-residue polypeptide by exchange of residues in selected positions.

\section{Acknowledgements}

We thank the Schweizerische Nationalfonds for support of this work.

\section{References}

Barany,G. and Merrifield,R.B. (1979) In Gross,E. and Meienhofer,J. (ods), The Peptides. Vol. 2, Academic Press, NY, pp. 1-284.

Beaucage,S.L. and Caruthers,M.H. (1981) Tetrahedron Letr., 22, 1859-1862.

Bimboim,H.C. and Doly.J. (1979) Nucleic Acids Res., 7, 1513-1523.

Chou,P.Y. and Fasman,G.D. (1978) Adv. Enzymol., 47, 45-148.

Craven,G.R., Steers, E. Jr and Anfinsen,C.B. (1965) J. Biol. Chem., 240. $2468-2477$.

Cuatrecasas,P. (1970) J. Biol. Chem., 245, 3059-3065.
Dörper, T. and Winnacker,E.-L. (1983) Nucleic Acids Res., 11, 2572-2584. Goldschmidt,R. (1970) Narure, 228, 1151-1154.

Grosjean, H. and Fiers, W. (1982) Gene, 18, 199-209.

Gutte,B., Moser,R., Klauser,S. and Weilenmann,M. (1984) In Ricard,J. and Comish-Bowden,A. (eds), Dynamics of Biochemical Systems. Plenum Publishing Corporation, NY, pp. 259-272.

Hummel,J.P. and Dreyer, W.J. (1962) Biochim. Biophys. Acta, 63, 530-532.

Itakura,K., Hirose,T., Crea,R., Riggs, A.D., Heyneker,H.L., Bolivar,F. and Boyer,H.W. (1977) Science, 198, 1056-1063.

Langley,K.E., Fowler,A.V. and Zabin,I. (1975) J. Biol. Chem., 250, 2587-2592.

Levitt,M. (1978) Biochemistry, 17, 4277-4285.

Marko,M.A., Chipperfiek, R. and Bimboim,H.C. (1982) Anal. Biochem., 121, 382-387.

Maxam,A.M. and Gilbert,W. (1980) Methads Enzymol., 65, 499-560.

Merrifield,R.B. (1963) J. Am. Chem. Soc., 85, 2149-2154.

Moser,R. (1986) Ph.D. Thesis, Universität Zürich.

Moser,R., Thomas,R.M. and Gutte,B. (1983) FEBS Lett., 157, 247-251.

Moser,R., Klauser,S., Leist,T., Langen,H., Epprecht,T. and Gutte,B. (1985) Angew. Chem. (Engl. Ed.), 24, 719-727.

Rommens,J., MacKnight,D., Pomeroy-Cloney,L. and Jay,E. (1983) Nucteic Acids Res., 11, $5921-5940$.

Rüther,U. and Müller-Hill,B. (1983) EMBO J., 2, 1791-1794.

Sakurai,H. (1980) Chem. Pharm. Bull., 28, 3437-3439.

Steers,E. Jr, Craven,G.R, Anfinsen,C.B. and Bethune,J.L. (1965) J. Biol. Chem. 240, $2478-2484$.

Steers,E.,Jr, Cuatrecasas,P. and Pollard,H.B. (1971) J. Biol. Chem., 246, $196-200$.

Ullmann,A., Jacob,F. and Monod,J. (1967) J. Mol. Biol., 24, 339-343.

Vieira,J. and Messing,J. (1982) Gene, 19, 259-268.

Yanisch-Perron,C., Vieira,J. and Messing,J. (1985) Gene, 33, 103-111.

Received on March 13, 1987; revised on June 4, 1987 